\title{
Three new asymmetric trans-amine(azole)dichloridoplatinum complexes that overcome cisplatin resistance and their reactions with 5'-GMP
}

\author{
Elena Pantoja a , Agata Gallipoli a, Steven van Zutphen a, Seiji Komeda a, \\ Desigan Reddy ${ }^{b}$, Deogratius Jaganyi ${ }^{b}$, Martin Lutz ${ }^{c}$, Duncan M. Tooke ${ }^{c}$, \\ Anthony L. Spek ${ }^{\text {c }}$, Carmen Navarro-Ranninger ${ }^{d}$, Jan Reedijk ${ }^{\text {a,* }}$ \\ ${ }^{a}$ Leiden Institute of Chemistry, Gorlaeus Laboratories, Leiden University, P.O. Box 9502, 2300 RA Leiden, The Netherlands \\ ${ }^{\mathrm{b}}$ School of Chemistry, University of KwaZulu-Natal, Private Bag X01, Scottsville, Pietermaritzburg 3209, South Africa \\ ${ }^{c}$ Department of Crystal and Structural Chemistry, Utrecht University Padualaan 8, 3584 CH, Utrecht, The Netherlands \\ d Departamento de Química Inorgánica, Universidad Autónoma de Madrid, 28049 Madrid, Spain
}

Received 30 June 2006; received in revised form 7 September 2006; accepted 8 September 2006

Available online 28 September 2006

\begin{abstract}
Three new asymmetric platinum(II) complexes comprising an isopropylamine ligand trans to an azole ligand were synthesized and fully characterized by ${ }^{1} \mathrm{H}$ NMR, ${ }^{195} \mathrm{Pt}$ NMR, IR and elemental analysis. In addition the X-ray crystal structure of all three complexes was determined. The reaction kinetics of the complexes with DNA model base guanosine-5'-monophosphate (GMP) was studied, revealing reaction kinetics comparable to cisplatin. To gain insight in the complexes as potential antitumor agents, cytotoxicity assays were performed on a variety of human tumor cell lines. These assays showed the complexes all to possess cytotoxicity profiles comparable to cisplatin. Furthermore, the complexes largely retain their activity in a human ovarian carcinoma cell line resistant to cisplatin, A2780R, compared to the cisplatin sensitive parent cell line A2780. These results are of fundamental importance, illustrating how platinum complexes of trans geometry can show improved activity compared to cisplatin in both cisplatin sensitive and cisplatin resistant cell lines.
\end{abstract}

(C) 2006 Elsevier Inc. All rights reserved.

Keywords: trans-Platinum; Anticancer; Chlorido; Guanosine monophosphate; Amine; Azole

\section{Introduction}

Cisplatin, cis-[ $\left.\mathrm{PtCl}_{2}\left(\mathrm{NH}_{3}\right)_{2}\right]$, has received worldwide acceptance as a clinical drug for the treatment of various neoplastic diseases, including testicular, ovarian and head and neck cancer $[1,2]$. Unfortunately, the drug has some important limitations, including dose-limiting toxicities, and the development of drug resistance [3-5]. Therefore, much study has focused on finding alternative platinum compounds with improved clinical profiles. In the early

\footnotetext{
* Corresponding author. Tel.: +31 715274459; fax: +31 715274671.

E-mail address: reedijk@chem.leidenuniv.nl (J. Reedijk).
}

structure-activity relationship studies it was found that while cisplatin is endowed with cytotoxic properties, its congener transplatin is therapeutically inactive [6-8]. The cis geometry was therefore postulated to be essential for platinum complexes to display antitumor activity. The binding of a platinum complex to DNA is the key step that sets off the apoptotic pathways in tumor cells $[9,10]$. More specifically the activity of cisplatin is thought to be related to its ability to form 1,2-intrastrand cross-links between two adjacent guanines [11-13]. On the other hand, if transplatin, binds a guanine base, it is more likely to transform into an interstrand adduct involving the complementary cytosine, than to bind the adjacent base on the same strand 
of DNA [12,14]. It is this difference in DNA-platinum adducts formation that may be the reason for the difference in antitumor activity observed between cis- and transplatin. However, while this structure-activity relationship may hold for complexes containing $\mathrm{NH}_{3}$ or aliphatic amines as non-leaving groups $[8,15,16]$, more recently it was found that it does not apply for trans-platinum compounds in which platinum carries planar $\mathrm{N}$-heterocyclic amines or aromatic amines as non-replaceable ligands [15-19]. Although these compounds cannot interact with DNA in the same manner as cisplatin, complexes where one or both of the $\mathrm{NH}_{3}$ ligands of trans- $\left[\mathrm{PtCl}_{2}\left(\mathrm{NH}_{3}\right)_{2}\right]$ have been replaced with planar ligands such as pyridine, thiazole, quinoline, imidazole or non-planar heterocyclic amine ligands, such as piperidine derivates can display higher cytotoxicity than either their cis analogues or even cisplatin. It is thought these complexes bind DNA both through coordination of the platinum and through intercalation of the aromatic ligand [20].

In the present paper, three new asymmetric trans-platinum complexes consisting of an isopropylamine ligand (iPram) trans to an azole ligand are described. Such sterically demanding carrier ligands decrease the rate of replacement of the chlorido ligands since the five-coordinate intermediate species, usually formed during ligand substitution reactions, does not readily form [21]. In general this is likely to lead to activation of the trans geometry and a reduction in the toxic side-effect [22]. The three azole ligands selected were pyrazole (Hpz), 1-methylimidazole (Meim) and 1-methylpyrazole (Mepz). These azole ligands make the environment of the central platinum distinct, through the presence of an $\mathrm{H}$-bond donor for $\mathrm{Hpz}$, increased steric hindrance for Mepz and neither of these factors for Meim. This increase is likely to influence the reactivity and DNA binding abilities of the complexes, which may lead to different cytotoxic behaviors. The combination of both aliphatic and aromatic carrier ligands was chosen based on the fact that the symmetric trans-platinum complexes with either aliphatic or aromatic ligands showed improved antitumor activity compared to their cis analogues $[21,22]$. We reasoned that the asymmetry in the presented complexes, as well as increasing the cytotoxicity in cisplatin sensitive cell lines, may also lead to an increase in activity in cisplatin resistant cell lines. The complexes were synthesized and their crystal and molecular structures were determined. Subsequently, the DNA binding of the complexes was studied with a model reaction with GMP, while the cytotoxic behavior was studied on a number of human tumor cell lines including a cell line with acquired resistance to cisplatin treatment.

\section{Experimental}

\subsection{Materials and measurements}

$\mathrm{K}_{2} \mathrm{PtCl}_{4}$ was provided by Johnson \& Matthey (Reading, UK). Isopropylamine, sodium perchlorate monohydrate
$\left(\mathrm{NaClO}_{4} \cdot \mathrm{H}_{2} \mathrm{O}, 98 \%\right), \quad N, N$-dimethylformamide (DMF) and perchloric acid were obtained from Sigma-Aldrich and used as received. The disodium salt of $5^{\prime}$-GMP $\left(\mathrm{Na}_{2} \mathrm{GMP}, 99 \%\right)$ was also obtained from Sigma-Aldrich and was stored in a desiccator at ca. $4{ }^{\circ} \mathrm{C}$ and used without further purification. Pyrazole, 1-methylimidazole and 1-methylpyrazole were obtained from Fisher Scientific Nederland B.V.

Elemental analysis was performed on a Perkin-Elmer series II CHNS/O Analyzer model 2400. NMR spectra were recorded on a Bruker DPX 300. The temperature was kept constant (at $298 \mathrm{~K}$ for the characterization of the complexes and at $310 \mathrm{~K}$ for the GMP reactions) by a variable temperature unit. ${ }^{1} \mathrm{H}$ and ${ }^{195} \mathrm{Pt}$ NMR were measured in chloroform (for the final complexes) and $\mathrm{D}_{2} \mathrm{O}$ (for the GMP reactions). FTIR spectra were obtained on a Perkin-Elmer Paragon 1000 FTIR spectrophotometer equipped with a Golden Gate ATR device, using the diffuse reflectance technique in the range $4000-300 \mathrm{~cm}^{-1}$ (resolution $4 \mathrm{~cm}^{-1}$ ). Mass spectrometry was performed on a Finnigan TQS700 instrument.

\subsection{Synthesis of cis-[PtCl$\left.{ }_{2}(\text { iPram })_{2}\right]$}

$\mathrm{K}_{2} \mathrm{PtCl}_{4}(1 \mathrm{~g}, 2.4 \mathrm{mmol})$ was dissolved in water $(50 \mathrm{~mL})$ and treated with $3.88 \mathrm{~g}(23.4 \mathrm{mmol})$ of KI. The solution was stirred for $1 \mathrm{~h}$ at room temperature. Two equivalents of isopropylamine (iPram) $(4.8 \mathrm{mmol})$ were added to the $\mathrm{K}_{2} \mathrm{PtI}_{4}$ solution. The reaction was stirred for $4 \mathrm{~h}$. The yellow precipitate was washed with water, methanol and diethyl ether. The final product $c i s-\left[\mathrm{PtI}_{2}(\mathrm{iPram})_{2}\right]$ was dried in air $\left(1.29 \mathrm{~g}\right.$, yield: $95 \%$ ) and checked by ${ }^{1} \mathrm{H}$ NMR (Acetone- $d_{6}: \delta(\mathrm{ppm}): 3.57,2 \mathrm{H}$, sept; $\left.1.37,12 \mathrm{H}, \mathrm{d}\right)$ and ${ }^{195} \mathrm{Pt}$ NMR (acetone- $\left.d_{6}: \delta(\mathrm{ppm}):-3342\right)$. A suspension of $c i s-$ $\left[\mathrm{PtI}_{2}(\mathrm{Pram})_{2}\right](1.29 \mathrm{~g}, 2.28 \mathrm{mmol})$ in $80 \mathrm{~mL}$ of water was treated with 1.85 equiv of $\mathrm{AgNO}_{3}$ overnight in the dark. Precipitated $\mathrm{AgI}$ was filtered off and 4 equiv of $\mathrm{KCl}$ were added to the filtrate. The reaction mixture was stirred for $4 \mathrm{~h}$ at $40{ }^{\circ} \mathrm{C}$ and allowed overnight at $4{ }^{\circ} \mathrm{C}$. The yellow solid was filtered, washed with water, and dried in air. The final product was characterized by ${ }^{1} \mathrm{H}$ NMR (DMSO- $d_{6}: \delta(\mathrm{ppm}): 3.09,2 \mathrm{H}$, sept; $\left.1.20,12 \mathrm{H}, \mathrm{d}\right)$ and ${ }^{195} \mathrm{Pt}$ NMR (DMSO- $\left.d_{6}: \delta(\mathrm{ppm}):-2210\right)$.

\subsection{Synthesis of the trans-Pt(II) complexes}

A suspension of $c i s-\left[\mathrm{PtCl}_{2}(\mathrm{iPram})_{2}\right](0.2 \mathrm{~g}, 0.521 \mathrm{mmol})$ in water $(8 \mathrm{~mL})$ was treated with 1.9 equiv of the azole ligand, pyrazole (Hpz), 1-methylimidazole (Meim) and 1-methylpyrazole (Mepz), respectively. The mixture was stirred and heated at $70^{\circ} \mathrm{C}$ until a clear yellow solution was obtained and then brought to reflux for about $1 \mathrm{~h}$. Subsequently, the solution was allowed to cool to room temperature, and conc. hydrochloric acid $(0.364 \mathrm{~mL})$ was added. The solution was heated to reflux for $6 \mathrm{~h}$ and then cooled down in an ice bath and stored at $4{ }^{\circ} \mathrm{C}$ overnight, to increase the yield of the reaction. The product was 


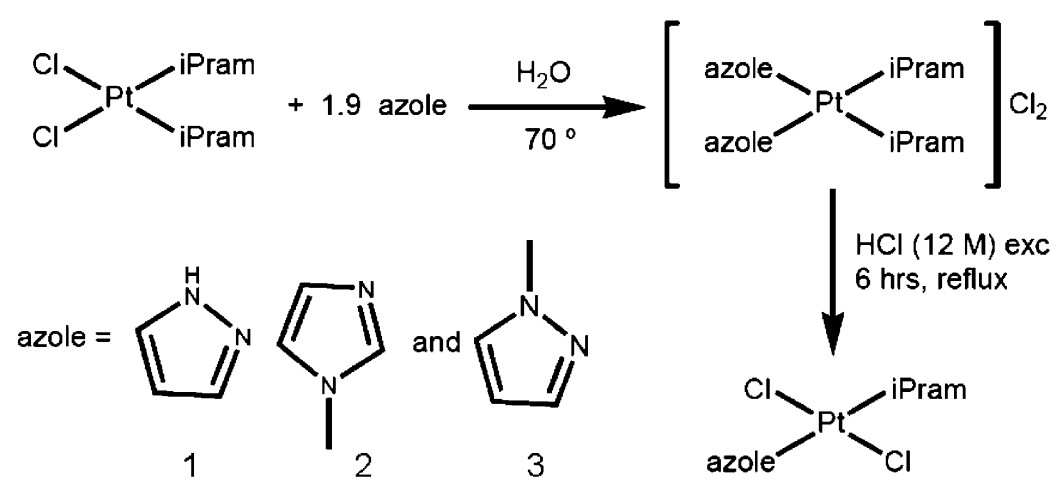

Scheme 1. Synthetic scheme for the asymmetric trans-platinum(II) complexes.
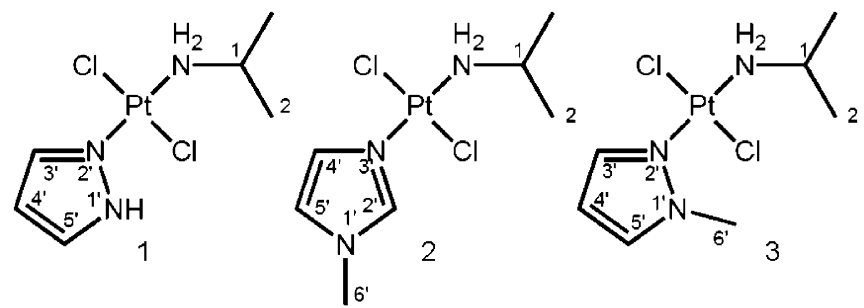

Fig. 1. Schematic representation of complexes trans- $\left[\mathrm{PtCl}_{2}(\mathrm{PPram})(\mathrm{Hpz})\right]$ (1), trans $-\left[\mathrm{PtCl}_{2}(\mathrm{iPram})(\mathrm{Meim})\right](\mathbf{2})$ and trans- $\left[\mathrm{PtCl}_{2}(\mathrm{iPram})(\mathrm{Mepz})\right](3)$.

collected by filtration and washed with water (see Scheme 1 for an overview), obtaining the pure desired complexes: trans- $\left[\mathrm{PtCl}_{2}(\mathrm{iPram})(\mathrm{Hpz})\right](\mathbf{1})$, trans $-\left[\mathrm{PtCl}_{2}(\mathrm{iPram})(\mathrm{Meim})\right]$ (2) and trans-[ $\left.\mathrm{PtCl}_{2}(\mathrm{iPram})(\mathrm{Mepz})\right]$ (3) [23]. Yield: (1) $0.127 \mathrm{~g}(60 \%)$, (2) $0.164 \mathrm{~g}(75 \%)$ and (3) $0.157 \mathrm{~g} \mathrm{(72 \% ).}$

The resulting complexes (see Fig. 1), were characterized by ${ }^{1} \mathrm{H}$ and ${ }^{195} \mathrm{Pt}$ NMR (Table 1), and by elemental analysis. Data for elemental analysis are: (1) Theory \% $\left(\mathrm{PtCl}_{2} \mathrm{C}_{6} \mathrm{H}_{13} \mathrm{~N}_{3}\right)$ : C: 18.33, H: 3.33, N: 10.69; Found \%: C: $18.62, \mathrm{H}: 3.20, \mathrm{~N}: 10.01$; (2) Theory $\%\left(\mathrm{PtCl}_{2} \mathrm{C}_{7} \mathrm{H}_{15} \mathrm{~N}_{3}\right)$ : C: 20.65, H: 3.71, N: 10.32; Found \%: C: 20.74, H: 3.90, $\mathrm{N}: 10.53$; (3) Theory $\%\left(\mathrm{PtCl}_{2} \mathrm{C}_{7} \mathrm{H}_{15} \mathrm{~N}_{3}\right)$ : C: $20.65, \mathrm{H}: 3.71$, $\mathrm{N}: 10.32$; Found \%: C, 20.54, H, 3.80, N: 10.43 .

\subsection{X-ray structural determinations}

Single crystals of complexes $\mathbf{1}, \mathbf{2}$ and $\mathbf{3}$ were obtained by slow evaporation of their saturated $\mathrm{CDCl}_{3}$ solutions, directly from the NMR tube. X-ray intensities were measured on a Nonius KappaCCD diffractometer with rotating anode $(\lambda=0.71073 \AA)$ at a temperature of $150(2) \mathrm{K}$. The data were corrected for absorption using the program SADABS [24]. The structures were solved with automated
Patterson methods (compounds 1 and 2, DIRDIF-97 [25]) or direct methods (compound 3, SHELXS-86 [26]) and refined with SHELXL-97 [27] against $F^{2}$ of all reflections. Non-hydrogen atoms were refined freely with anisotropic displacement parameters; hydrogen atoms were refined as rigid groups. Molecular illustration, structure checking and calculations were performed with PLATON package [28]. The entries CCDC 265233 (compound 1), CCDC 224778 (compound 2) and CCDC 265232 (compound 3) contain supplementary crystallographic data for the three complexes in this paper. These data can be obtained free of charge via www.ccdc.cam.ac.uk/conts/retrieving.html (or from CCDC, 12 Union Road, Cambridge CB2 1EZ, UK; fax: +44 1223 336033; e-mail: deposit@ccdc.cam. ac.uk). A summary of the crystal structure determination for complex $\mathbf{1}$ is given in Table 2 (for complexes $\mathbf{2}$ and $\mathbf{3}$, see supplementary information Table S1).

\subsection{Cytotoxicity test: cell lines and culture conditions}

The cell lines used were MCF7 and EVSA-T (breast cancer), WIDR (colon cancer), IGROV (ovarian cancer), M19 (melanoma), A498 (renal cancer), and H226 (non-small cell lung cancer). Cell lines WIDR, M19, A498, IGROV and H226 belong to the currently used anticancer screening panel of the National Cancer Institute, USA [29]. All cell lines were maintained in a continuous logarithmic culture in RPMI 1640 medium with Hepes and phenol red. The medium was supplemented with $10 \%$ fetal calf serum (FCS), penicillin $100 \mathrm{IU} / \mathrm{mL}$ and streptomycin $100 \mu \mathrm{g} /$ $\mathrm{mL}$. The cells were mildly trypsinized for passage and for use in the experiments. Cisplatin and complexes, 1, 2 and 3, were initially dissolved in DMSO $(1 \mathrm{mg} / \mathrm{mL})$. A 3-fold aqueous dilution sequence of 10 steps was used in quadruplicate. After $48 \mathrm{~h}$ pre-incubation of the tumors cells in

Table 1

${ }^{1} \mathrm{H}$ and ${ }^{195} \mathrm{Pt}$ NMR data for the trans-Pt(II) complexes (solvent: $\mathrm{CDCl}_{3}$ )

\begin{tabular}{llll}
\hline Complex & Azole, $\delta\left({ }^{1} \mathrm{H}\right), \mathrm{ppm}$ & iPram, $\delta\left({ }^{1} \mathrm{H}\right), \mathrm{ppm}$ & $\delta\left({ }^{195} \mathrm{Pt}\right), \mathrm{ppm}$ \\
\hline $\mathbf{1}$ & $11.69\left[\mathrm{H} 1^{\prime}(\mathrm{s})\right], 8.13\left[\mathrm{H}^{\prime}(\mathrm{d})\right], 6.38\left[\mathrm{H}^{\prime}(\mathrm{t})\right], 7.59\left[\mathrm{H} 5^{\prime}(\mathrm{d})\right]$ & $3.41[\mathrm{H} 1(\mathrm{sept})], 1.38[\mathrm{H} 2(\mathrm{~d})]$ & -2168 \\
$\mathbf{2}$ & $3.7\left[\mathrm{H}^{\prime}(\mathrm{s})\right], 8.02\left[\mathrm{H}^{\prime}(\mathrm{s})\right], 6.79\left[\mathrm{H}^{\prime}(\mathrm{d})\right], 7.42\left[\mathrm{H} 5^{\prime}(\mathrm{d})\right]$ & $3.43[\mathrm{H} 1(\mathrm{sept})], 1.37[\mathrm{H} 2(\mathrm{~d})]$ & -2118 \\
$\mathbf{3}$ & $4.13\left[\mathrm{H6}^{\prime}(\mathrm{s})\right], 7.58\left[\mathrm{H}^{\prime}(\mathrm{s})\right], 6.35\left[\mathrm{H}^{\prime}(\mathrm{d})\right], 7.95\left[\mathrm{H} 5^{\prime}(\mathrm{d})\right]$ & $3.10[\mathrm{H} 1(\mathrm{sept})], 1.16[\mathrm{H} 2(\mathrm{~d})]$ & -2119 \\
\hline
\end{tabular}


Table 2

Crystal data for complex trans-[ $\left.\mathrm{PtCl}_{2}(\mathrm{iPram})(\mathrm{Hpz})\right](\mathbf{1})$

\begin{tabular}{|c|c|c|c|}
\hline & 1 & & 1 \\
\hline $\begin{array}{l}\text { Chemical } \\
\text { formula }\end{array}$ & {$\left[\mathrm{PtCl}_{2} \mathrm{C}_{7} \mathrm{H}_{13} \mathrm{~N}_{3}\right]$} & Crystal color & Colorless \\
\hline $\begin{array}{l}\text { Formula } \\
\text { weight }\end{array}$ & 397.17 & Crystal size $\left[\mathrm{mm}^{-3}\right]$ & $0.30 \times 0.08 \times 0.18$ \\
\hline $\begin{array}{l}\text { Crystal } \\
\text { system }\end{array}$ & Monoclinic & No. refl. measured & 27690 \\
\hline $\begin{array}{l}\text { Space } \\
\text { group }\end{array}$ & $\mathrm{P} 2{ }_{1} / c$ & No. unique refl. & 2409 \\
\hline$a[\AA]$ & $8.2538(10)$ & No. parameters & 111 \\
\hline$b[\AA]$ & $7.7014(10)$ & $R_{1}$ (all refl.) & 0.0245 \\
\hline$c[\AA]$ & $16.8804(10)$ & $R_{1}$ (obs. refl.) & 0.0171 \\
\hline$\alpha[\mathrm{deg}]$ & 90 & w $R_{2}$ (all refl.) & 0.0314 \\
\hline$\beta[\mathrm{deg}]$ & $99.956(10)$ & w $R_{2}$ (obs. refl.) & 0.0299 \\
\hline$\gamma[\operatorname{deg}]$ & 90 & $(\sin \theta / \lambda)_{\max }\left(\AA^{-1}\right)$ & 0.77 \\
\hline$V\left[\AA^{3}\right]$ & $1056.9(2)$ & $R_{\text {int }}$ & 0.043 \\
\hline$Z$ & 4 & GoF (goodness of fit) & 1.03 \\
\hline$\rho_{\text {calc }}\left[\mathrm{g} / \mathrm{cm}^{3}\right]$ & 2.471 & Transmission & $0.35-0.66$ \\
\hline$\mu\left[\mathrm{mm}^{-1}\right]$ & 13.735 & $\begin{array}{l}\text { Residual electron } \\
\text { density }\left(\mathrm{e} / \AA^{3}\right)\end{array}$ & $(-0.91)-0.84$ \\
\hline
\end{tabular}

96-wells flat-bottom microtiter plates, the solutions of the test compounds were added. The plates were incubated at $37{ }^{\circ} \mathrm{C}, 8.5 \% \mathrm{CO}_{2}$ for $120 \mathrm{~h}$. $\mathrm{IC}_{50}$ values were determined using the microculture sulforhodamine B (SRB) test [30]. Cell survival was evaluated by measuring the absorbance at $540 \mathrm{~nm}$ using an automated microplate reader (Labsystems Multiskan MS).

The cell lines A2780 and A2780res, i.e. ovarian cancer cell lines derived from untreated patient cells [31], were maintained in continuous logarithmic culture Dulbecco's modified Eagle's Medium (DMEM) (Gibco-BRL ${ }^{\mathrm{TM}}$, Invitrogen Corporation, NL) supplemented with $10 \%$ Fetal Medium Serum (Perbio Science, Belgium), PenicillinG Sodium (100 U/mL Duchefa Biochemie BV, NL), Streptomycin $(100 \mu \mathrm{g} / \mathrm{mL}$ Duchefa Biochemie BV, NL) and Glutammax 100× (Gibco-BRL $\left.{ }^{\mathrm{TM}}, \mathrm{NL}\right)$. Cells, which survive in cultures treated with the compounds, were evaluated using the so-called MTT method [32]. Compounds were added in microwells containing the cell culture at final concentrations of $0-200 \mu \mathrm{M} ; 48 \mathrm{~h}$ later, cell survival was evaluated by measuring the absorbance at $520 \mathrm{~nm}$, using a BIO-RAD microplate model 550. The $\mathrm{IC}_{50}$ values (i.e. the concentration of the complex that restricts cell growth to $50 \%$ of that compared with the control) were calculated from curves constructed by plotting cell survival (\%) versus compound concentration $(\mu \mathrm{M})$. All experiments were carried out in triplicate.

\subsection{Reactions of 1, 2 and $\mathbf{3}$ with GMP monitored by NMR}

GMP was reacted with $\mathbf{1}, \mathbf{2}$ and 3 by using excess (1:4) amount of GMP in $250 \mu \mathrm{L} 0.1 \mathrm{M} \mathrm{NaClO}{ }_{4} / \mathrm{D}_{2} \mathrm{O}$ in a NMR tube. The three complexes were first pre-dissolved in $30 \mu \mathrm{L}$ of DMSO- $d_{6}$ for complex 1 or DMF- $d_{7}$ for complex $\mathbf{2}$ and $\mathbf{3}$, respectively; because of the poor solubility of the complexes in water; this was followed by the addition of $480 \mu \mathrm{L}$ of water. The reactions were left to incubate at $310 \mathrm{~K}$ in the dark. The reactions were monitored by recording ${ }^{1} \mathrm{H}$ NMR spectra at time intervals of 30 min during the overnight reaction, and after every $24 \mathrm{~h}$ until no further changes were observed. Subsequently, at the end of the reactions ${ }^{195} \mathrm{Pt}$ NMR was measured from the same solution in the same NMR tube and mass spectrometry was recorded from this tube as well.

\subsection{Kinetic measurements and preparation of the solutions}

Substitution of the chlorido ligands by GMP were followed spectrophotometrically, using a Cary 100 Bio UV/ visible Spectrophotometer, equipped with a Varian Peltier temperature controller. The spectral changes of the reactions were recorded over the wavelength range of 190 $800 \mathrm{~nm}$. All kinetic data were then graphically analysed using the software package, Origin $5.0^{\circledR}[33]$.

These reactions were initiated by mixing equal volumes of GMP and complex solution in a tandem cuvette, thermostated in a spectrophotometer cell compartment maintained within approximately $0.1^{\circ} \mathrm{C}$ at $30^{\circ} \mathrm{C}$.

Solutions of the azole complexes were prepared by first pre-dissolving an appropriate quantity of the $\mathrm{Pt}(\mathrm{II}) \mathrm{com}$ plex in $N, N$-dimethylformamide (DMF), and subsequently adding the required amount of aqueous $0.1 \mathrm{M} \mathrm{NaClO}_{4}$, prepared using ultrapure water, afford the desired concentration with a $5 \%(\mathrm{v}: \mathrm{v})$ ratio of DMF: $0.1 \mathrm{M} \mathrm{NaClO}_{4}$.

The GMP solution was prepared by dissolving an appropriate quantity of the nucleophile in a solution of constant ionic strength $\left(0.1 \mathrm{M} \mathrm{NaClO}_{4}\right)$. The perchlorate ion, $\mathrm{ClO}_{4}^{-}$, is not known to coordinate $\mathrm{Pt}(\mathrm{II})$ [34] and hence the substitution reactions of the platinum complexes with GMP are unaffected by the presence of this ion.

\section{Results and discussion}

\subsection{Synthesis and characterization}

The synthesis of the asymmetric trans-platinum(II) complexes was accomplished through treatment of the symmetric tetra-amine complex with concentrated hydrochloric acid as illustrated in Scheme 1, based on literature procedures [23]. The complexes where fully characterized using ${ }^{1} \mathrm{H},{ }^{195} \mathrm{Pt}$ NMR (Table 1), IR, X-ray diffraction and elemental analysis. The elemental analysis data are consistent with the empirical formulas $\mathrm{C}_{6} \mathrm{H}_{13} \mathrm{~N}_{3} \mathrm{PtCl}_{2}$ (1), $\mathrm{C}_{7} \mathrm{H}_{15} \mathrm{~N}_{3} \mathrm{PtCl}_{2}$ (2), and $\mathrm{C}_{7} \mathrm{H}_{15} \mathrm{~N}_{3} \mathrm{PtCl}_{2}$ (3), confirming the $\left[\mathrm{PtCl}_{2}\right.$ (iPram)(azole)] structure. In the ${ }^{1} \mathrm{H}$ NMR $\left(\mathrm{CDCl}_{3}\right)$ spectra for all the platinum complexes, the signals corresponding to the azole ligands and for the iPram are shifted downfield, compared to each of the free ligands. The chemical shifts observed in the ${ }^{195} \mathrm{Pt}$ NMR (in $\mathrm{CDCl}_{3}$ ) confirmed a trans- $\left[\mathrm{PtN}_{2} \mathrm{Cl}_{2}\right]$ platinum coordination sphere (Table 1) $[33,34]$. The trans geometry is also supported by IR spectral data, where a single band at 342, 335 and $334 \mathrm{~cm}^{-1}$ for complex 1, 2 and 3, respectively, can be assigned to the stretching of the $\mathrm{Pt}-\mathrm{Cl}$ 
bonds [35]. The structure of each of the three complexes has been depicted schematically in Fig. 1.

\subsection{X-ray structure of the three complexes}

Single crystals of the complexes were obtained by slow evaporation of their saturated $\mathrm{CDCl}_{3}$ solutions, inside the NMR tube. In all of the three complexes the platinum atom is in a slightly distorted square planar configuration. Furthermore, it was observed that the Pt-N(azole) bonds are slightly shorter than the $\mathrm{Pt}-\mathrm{N}$ (amine) bonds as commonly observed in this type of complexes [15]. The $\mathrm{Pt}-\mathrm{Cl}$ bond lengths are in the expected range for all three complexes; similar distances were found in the crystal structure of other platinum complexes with the same donor environment [36-38].

Complex 1 was found to crystallize with only one molecule in the asymmetric unit. A molecular plot is presented in Fig. 2; selected bond distance angles and torsion angles are presented in Table 3 . Since the $\mathrm{Pt}-\mathrm{N} 2$ bond for the $\mathrm{Hpz}$ ligand is almost in the same plane as the ideal plane of this ligand, the torsion angle $\mathrm{Cl} 1-\mathrm{Pt} 1-\mathrm{N} 2-\mathrm{C} 3$ can be used to gauge the inclination of the ligand with respect to the equatorial plane around the Pt. This angle is $159.0(3)^{\circ}$ indicating that the $\mathrm{Hpz}$ ligand is slightly twisted with respect to

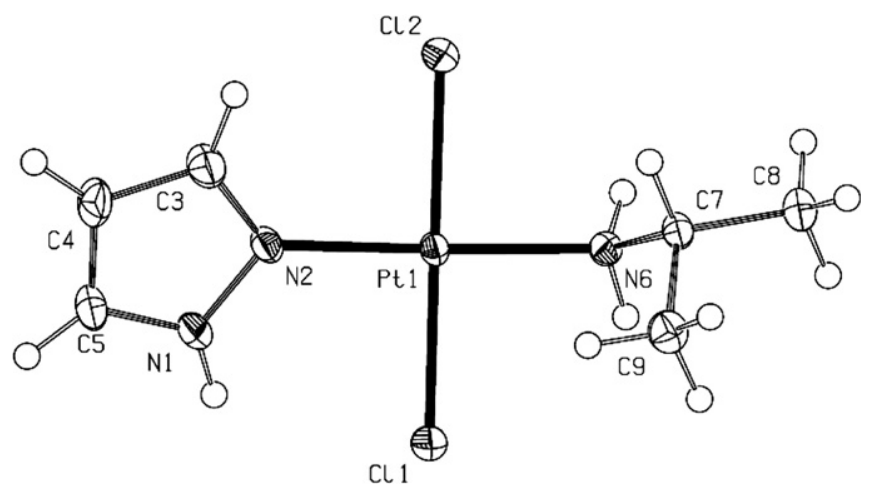

Fig. 2. Displacement ellipsoid plot $(50 \%$ probability $)$ of the trans$\left[\mathrm{PtCl}_{2}(\mathrm{iPram})(\mathrm{Hpz})\right]$ complex (1).

Table 3

Selected bond distances $(\AA)$, angles, and relevant torsion angles (deg) for trans- $\left[\mathrm{PtCl}_{2}(\mathrm{iPram})(\mathrm{Hpz})\right](\mathbf{1})$

\begin{tabular}{lc}
\hline Atoms & Distances and angles \\
\hline Pt1-N2 & $2.019(2)$ \\
Pt1-N6 & $2.041(2)$ \\
Pt1-Cl1 & $2.3027(8)$ \\
Pt1-Cl2 & $2.2905(8)$ \\
N2-Pt1-N3 & $176.39(10)$ \\
Cl1-Pt1-Cl2 & $174.69(3)$ \\
N2-Pt1-C11 & $90.96(7)$ \\
N2-Pt1-Cl2 & $90.32(7)$ \\
N6-Pt1-Cl1 & $90.90(7)$ \\
N6-Pt1-Cl2 & $88.11(7)$ \\
C11-Pt1-N2-C3 & $159.0(3)$ \\
C11-Pt1-N6-C7 & $-104.21(19)$ \\
\hline
\end{tabular}

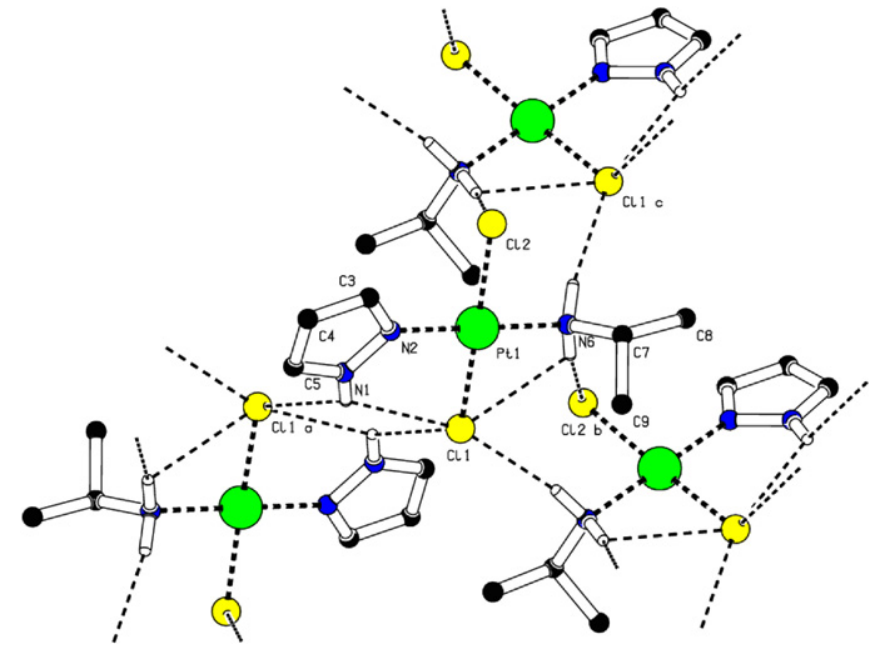

Fig. 3. Intramolecular hydrogen bonding between $\mathrm{N}-\mathrm{H}$ and $\mathrm{Cl}$ in complex trans-[ $\left.\mathrm{PtCl}_{2}(\mathrm{iPram})(\mathrm{Hpz})\right](\mathbf{1}) . \mathrm{C}-\mathrm{H}$ hydrogen atoms have been omitted for clarity.

Table 4

Hydrogen-bonding parameters and short contacts for trans- $\left[\mathrm{PtCl}_{2}\right.$ (iPram)(Hpz)] (1), symmetry operations: i: $-x, 1 / 2+y, 1 / 2-z$, ii: $-x$, $-1 / 2+y, 1 / 2-z$, iii: $-x,-y, 1-z$, iv: $x, 1 / 2-y, z$

\begin{tabular}{lllll}
\hline $\mathrm{D}-\mathrm{H} \cdots \mathrm{A}$ & $\mathrm{D}-\mathrm{H}[\AA]$ & $\mathrm{H} \cdots \mathrm{A}[\AA ⿻$ & $\mathrm{D} \cdots \mathrm{A}[\AA ⿻$ & $\mathrm{D}-\mathrm{H} \cdots \mathrm{A}[\mathrm{deg}]$ \\
\hline $\mathrm{N} 1-\mathrm{H} 1 \cdots \mathrm{Cl} 1$ & 0.88 & 2.60 & $3.087(3)$ & 116 \\
$\mathrm{~N} 1-\mathrm{H} 1 \cdots \mathrm{Cl} 1^{\mathrm{iii}}$ & 0.88 & 2.81 & $3.391(3)$ & 125 \\
$\mathrm{~N} 6-\mathrm{H} 6 \mathrm{~A} \cdots \mathrm{Cl} 2^{\mathrm{ii}}$ & 0.92 & 2.66 & $3.534(3)$ & 158 \\
$\mathrm{~N} 6-\mathrm{H} 6 \mathrm{~B} \cdots \mathrm{Cl} 1^{\mathrm{i}}$ & 0.92 & 2.54 & $3.451(2)$ & 170 \\
$\mathrm{C} 3-\mathrm{H} 3 \cdots \mathrm{Cl} 2$ & 0.95 & 2.80 & $3.226(3)$ & 108 \\
$\mathrm{C} 5-\mathrm{H} 5 \cdots \mathrm{Cl} 2^{\text {iv }}$ & 0.95 & 2.69 & $3.610(3)$ & 162 \\
\hline
\end{tabular}

the plane formed by $\mathrm{Cl} 1, \mathrm{Pt} 1, \mathrm{Cl} 2, \mathrm{~N} 6$. This small deviation can be due to the fact that the $\mathrm{H}$ next to the donor atom of the $\mathrm{Hpz}$ ligand can form a hydrogen bond with the $\mathrm{Cl}^{-}$ ligand located in the equatorial plane. Also, the Cl1-Pt1N6-C7 torsion angle is close to the dihedral angle between the Pt1, N6, C7 plane of the iPram ligand and the equatorial plane around the Pt. The fact that the torsion angle is $-104.21(29)^{\circ}$ shows that the ligand adopts a configuration that places the methyl group as far away as possible from the chloride ligands. The lattice structure of complex 1 consists of a one-dimensional zig-zag chain, build up by hydrogen bonds, as depicted in Fig. 3. The details for the hydrogen bonding geometry are given in Table 4 . The structures of complexes $\mathbf{2}$ and $\mathbf{3}$ are quite similar and are depicted in supplementary Figs. S1-S4. The Meim and Mepz ligands, for complexes $\mathbf{2}$ and 3, respectively, are orientated almost perpendicular to the equatorial plane, as a result of the steric hindrance of the methyl groups on the azole ring.

\subsection{Stability in water and reactivity with GMP of the complexes}

By studying the complexes in a $\mathrm{D}_{2} \mathrm{O} / \mathrm{H}_{2} \mathrm{O}(80 / 20)$ solution at $310 \mathrm{~K}$ over time using ${ }^{1} \mathrm{H}$ NMR spectroscopy, the 
aqueous stability was investigated. For this study, complex 1 was pre-dissolved in small amount $(<5 \%)$ of DMSO- $d_{6}$ while complexes 2 and 3 were pre-dissolved in DMF- $d_{7}$. For all three complexes the $\mathrm{pH}$ was followed with time and it was found to gradually decrease in the same order from $\mathrm{pH} 7.9$ to 7.2. Interestingly, for complexes $\mathbf{1}$ and $\mathbf{3}$ a new set of aromatic signals where observed downfield from the original signals after $8 \mathrm{~h}$, indicative of the hydrolysis of the $\mathrm{Pt}-\mathrm{Cl}$ bonds. Compound 2 remained stable for over 2 weeks. Clearly complex $\mathbf{2}$ is less prone to hydrolysis than the other two complexes. In contrast, when incubating the complexes with excess of GMP (1:4 for complex /GMP) at $310 \mathrm{~K}$, and following the reactions using ${ }^{1} \mathrm{H}$ NMR (Fig. 4), complex 2 appeared to react faster than either complex 1 or complex 3. In the case of complex 1 and $\mathbf{3}$ the intermediate Pt(iPram)(azole)GMP( $\left(\mathrm{OD}_{2}\right)$ (I, III (GM$\left.\mathrm{P}\left(\mathrm{OD}_{2}\right)\right)$ ) species was clearly observed 15 min after the start of the reaction (Fig. 4). This intermediate was not observed for complex 2. Ultimately the reactions all proceeded to form the Pt(iPram)(azole)bis(GMP) (I, II, III(GMP) $)_{2}$ ) (Fig. 4). For complex 2, this product was observed after $1.5 \mathrm{~h}$, and the reaction was completed after $48 \mathrm{~h}$ of reaction. For complex 3 the bisadduct was observed after $3 \mathrm{~h}$, and no further reaction was observed after $72 \mathrm{~h}$. Finally complex 1 needed $7 \mathrm{~h}$ for the formation of the bisadduct, and $96 \mathrm{~h}$ to reach completion. The structure of the final products was confirmed by mass spectrometry, and by ${ }^{195} \mathrm{Pt}$ NMR. The mass spectra showed a clear peak at the $\mathrm{m} / \mathrm{z}$ expected at 516.2, 531.1 and 531.8 for the I, II, III (GMP $)_{2}$ species, respectively. These values correspond to the mass of the bisadduct species with neutral GMPs ligands. In the ${ }^{195} \mathrm{Pt}$ NMR single peaks at $-2507,-2377$ and $-2380 \mathrm{ppm}$ were observed for compounds $\mathbf{1}, \mathbf{2}$ and $\mathbf{3}$ respectively, indicative of a $\left[\mathrm{PtN}_{4}\right]$ chromophore [39-43].

The interaction of the three complexes with stoichiometric amount (1:2) of GMP (Supp. Info) was also carried out. The behavior of the three complexes was found to be the same as in the reaction with excess of GMP, albeit somewhat slower.

\subsection{Kinetic aspects of complex 2 with $G M P$}

Since there was no overlapping in the peaks of the $\mathrm{H} 8$ proton region for compound $\mathbf{2}$ the kinetics of the reaction could be studied in more close detail. The variation of percentage of disappearance for the GMP has been analyzed in detail (Fig. 5), together with the appearance of the monoadduct (IICl(GMP)) and bisadduct $\left(\mathbf{I I}(\mathrm{GMP})_{2}\right)$. After $5 \mathrm{~h}$ from the beginning of the reaction the monoadduct and bisadduct appear to be present in about the same concentration, beyond this point the monoadduct start to decrease. It was found that $t_{1 / 4}$ of disappearance, i.e. the time needed for $25 \%$ of the free-GMP to disappear, was $3 \mathrm{~h}(180 \mathrm{~min})$. The time needed for $25 \%$ of the bisadduct to form, $t_{1 / 4}$ of formation, was found to be $4 \mathrm{~h}(240 \mathrm{~min})$. These values were determined graphically based on the relative integration values of the $\mathrm{H} 8$ proton. Clearly the steric factors and the $\mathrm{H}$-bond donor properties of compounds $\mathbf{1}$ and 3, respectively, stabilize the Pt(iPram)(azole)GM$\mathrm{P}\left(\mathrm{OD}_{2}\right)$ species. This leads to a slower reaction of the second nucleobases with the complexes. In compound $\mathbf{2}$ the methyl group on the imidazole ring is pointing away from the platinum so that the second nucleophile can come in more rapidly, and the platinum-bis(GMP) adduct is
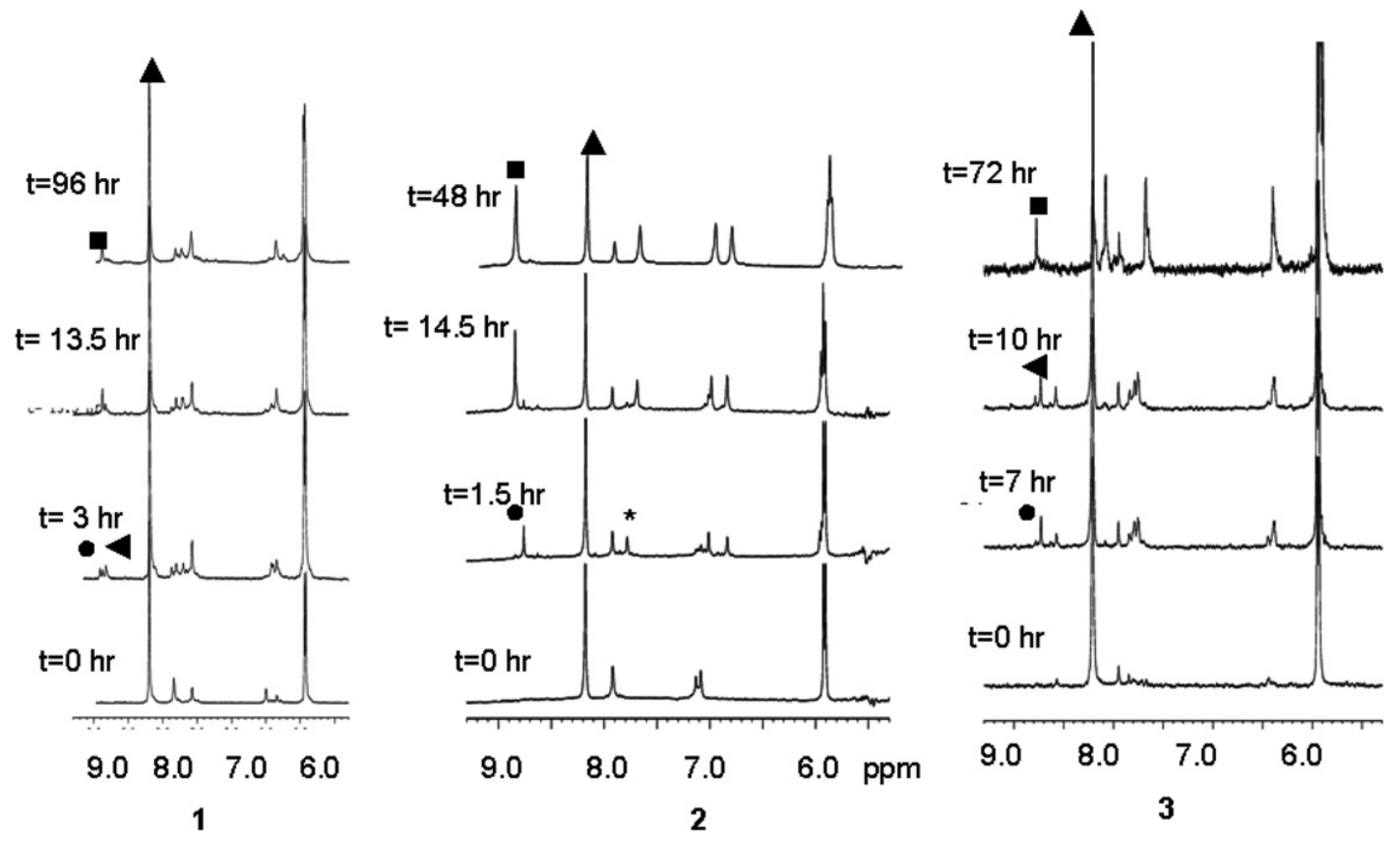

Fig. 4. ${ }^{1} \mathrm{H}$ NMR spectra in the aromatic region on the reaction of complexes $\mathbf{1}, \mathbf{2}$ and $\mathbf{3}$ with 4 equiv of GMP in $0.1 \mathrm{M} \mathrm{NaClO}_{4} / \mathrm{D}_{2} \mathrm{O}$ solution measured at $310 \mathrm{~K}$ as a function of time. The symbols show the H8 signals of GMP ligands in the products: I, II, III (GMP)Cl (๑); I, II, III(GMP(D $\left.\left(\mathrm{D}_{2} \mathrm{O}\right)\right)(\varangle)$; I, II, III $(\text { GMP })_{2}(\square)$; free-GMP $(\Delta)$. $(*)$ corresponds to a trace of DMF used to predissolve the complex. 


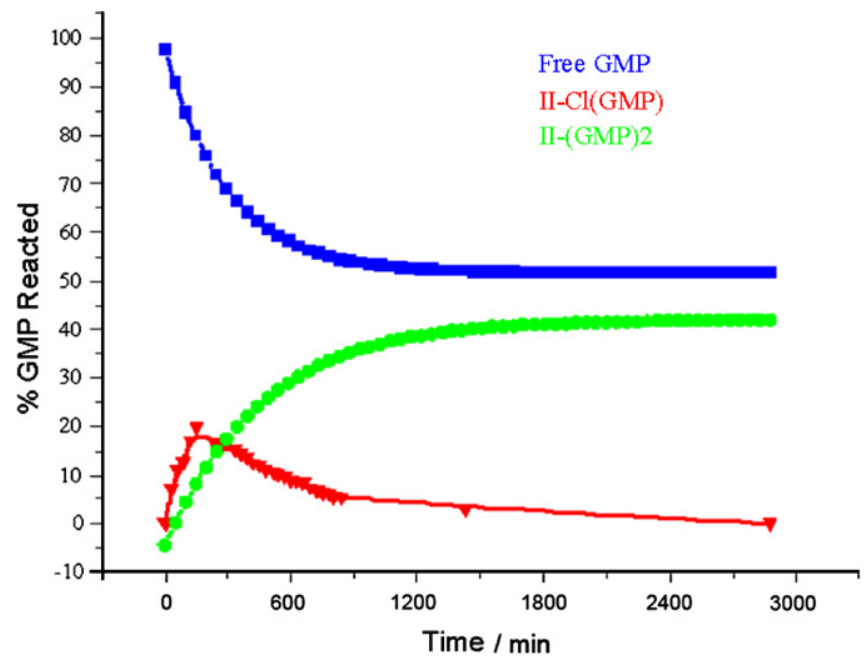

Fig. 5. Percentage of GMP reacted in the reaction of complex 2 with excess of GMP (conditions: $37^{\circ} \mathrm{C}$, in $\mathrm{NaClO}_{4}(10 \mathrm{mM})$ ).

formed at a higher rate. Based on these qualitative reactivity data, it was decided to perform a more detailed kinetic analysis for a few selected cases.

\subsection{Kinetic measurements and analyses}

Substitutions of the chlorido ligands were studied under pseudo first-order conditions. A known amount of GMP was dissolved in $25 \mathrm{~mL}$ of the constant ionic strength solution $0.1 \mathrm{M} \mathrm{NaClO}_{4}$, to afford a final concentration of ca. 100 times higher than that of the metal complexes. Subsequent dilutions with the same solution of $0.1 \mathrm{M} \mathrm{NaClO}_{4}$ afforded a series of concentrations, in the order of 20,40 , 60,80 and 100 times the concentration of the metal complexes.

All kinetic traces were best described by a single exponential equation. An example of the spectral change observed during the ligand substitution reaction is shown in Fig. 6. The plot of absorbance versus time at a specific wavelength used to determine the first observed rate constant, $k_{\text {obs } 1}$, is represented in the inset of Fig. 6. To investigate if the kinetic trace was made up by a double substitution, the data points were fitted using a two-exponential mode. The first $k_{\text {obs } 1}$ was the same as the one obtained using single exponential equation, while the second value was too small to be of any meaning. In expanding the kinetic trace for complex $\mathbf{3}$, it is clear that the first and second ligand substitution by GMP are very distinct and can be separated as shown in Fig. 7. These were therefore analysed independently, in the case of complex $\mathbf{3}$, to give the two $k_{\text {obs }}$.

The observed rate constants were found to be linearly dependent on the GMP concentration, as shown for complex 3 in Fig. 8 (see for details also Fig. S5 and S6 in Supp. Info for 1 and 2, respectively). The forward second-order rate constants, $k_{1}$ and $k_{2}$ for all the complexes were obtained from the slope of the linear regression while the

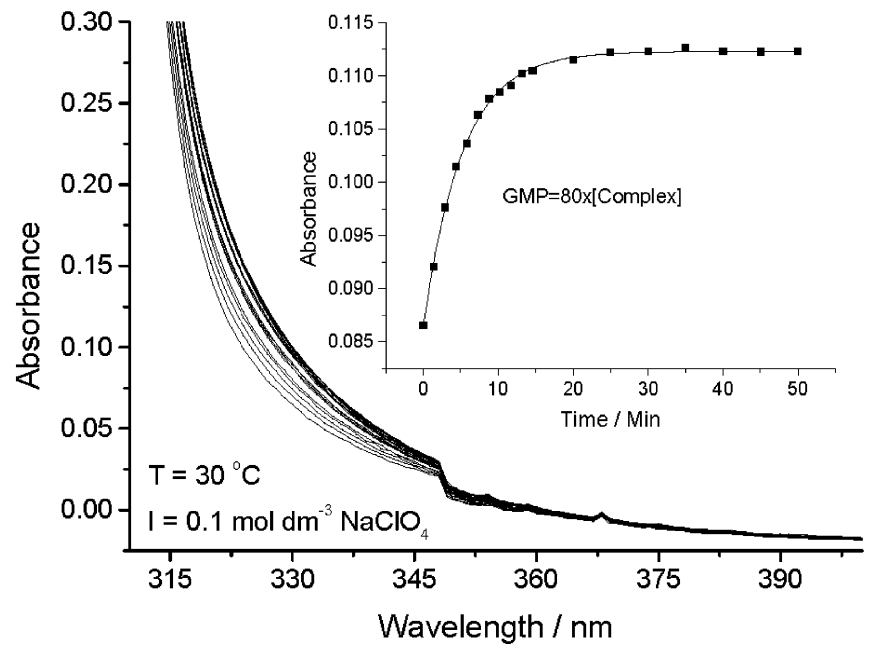

Fig. 6. UV-vis spectra obtained for the reaction of complex $\mathbf{3}$ and GMP at $30{ }^{\circ} \mathrm{C}$. Inset: plot of absorbance against time at $330 \mathrm{~nm}$.

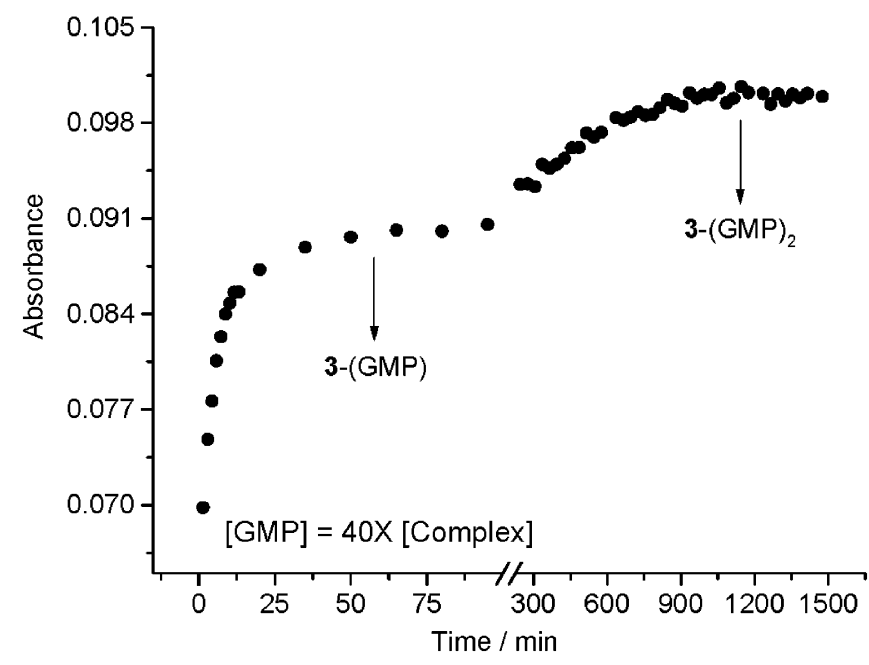

Fig. 7. Expanded plot of absorbance versus time at $330 \mathrm{~nm}$ to reveal the separation between the first and the second substitution involving GMP and 3, with GMP concentration being 40 times that of the metal complex.

intercepts of these plots resulted in the hydrolysis rate constants, $k_{\mathrm{s} 1}$ for all the complexes investigated and $k_{\mathrm{s} 2}$ for complex 3. The kinetic plots of concentration against $k_{\text {obs }}$ for all the complexes showed an intercept indicating the existence of a hydrolysis pathway. This means that the substitution reactions can be described by

$k_{\mathrm{obs} 1}=k_{1}[\mathrm{GMP}]+k_{\mathrm{s} 1}$

$k_{\mathrm{obs} 2}=k_{2}[\mathrm{GMP}]+k_{\mathrm{s} 2}$

The rate constant $k_{1}$ and $k_{2}$, obtained for the substitution reactions are given in Table 5. The values for the hydrolysis reaction, $k_{\mathrm{s} 1}$ and $k_{\mathrm{s} 2}$, are also shown. The results obtained show two hydrolysis steps, the forward reaction resulting in $\mathrm{Pt}(\mathrm{GMP})_{2}$ as the final product, as shown previously in the ${ }^{1} \mathrm{H}$ NMR study (Fig. 4). This conclusion can be generalized to be true for all the complexes even though the 


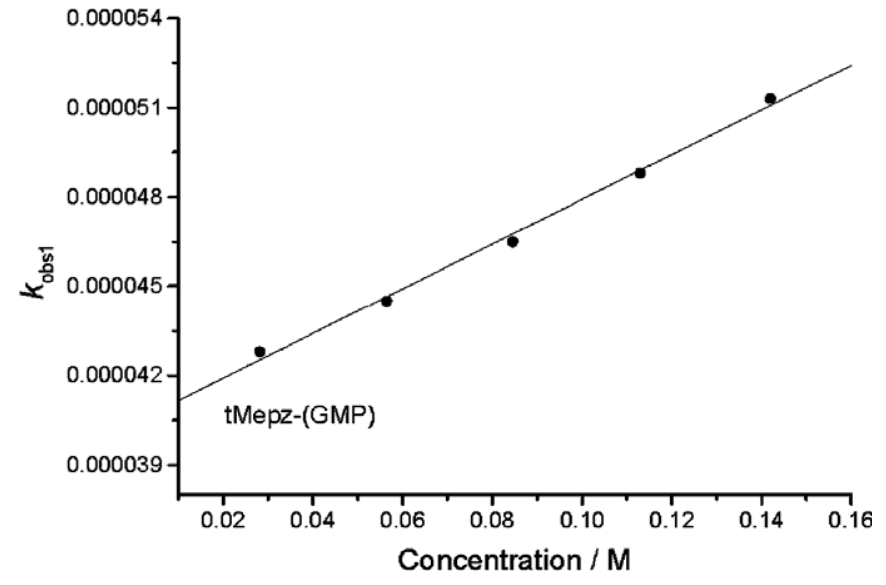

Fig. 8. Plot of $k_{\mathrm{obs} 1}$ versus GMP concentration for the complex 3 for the first substitution process. $I=0.1 \mathrm{M}\left(\mathrm{NaClO}_{4}\right), T=30^{\circ} \mathrm{C}$.

values for $k_{2}$ were not determined for complexes $\mathbf{1}$ and $\mathbf{2}$. This is because similar plots like Fig. 7 were obtained for these complexes. From a comparison of reactivity the second-order rate constants, $k_{1}$, decrease going from $\mathbf{1}$ $\left(1.86 \times 10^{-2} \mathrm{M}^{-1} \mathrm{~s}^{-1}\right)$ and $2\left(2.16 \times 10^{-4} \mathrm{M}^{-1} \mathrm{~s}^{-1}\right)$ to $\mathbf{3}$ $\left(7.55 \times 10^{-5} \mathrm{M}^{-1} \mathrm{~s}^{-1}\right)$. It is clear that the presence of the methyl group in the azole ring retards the substitution reaction depending on its position on the ring. This difference can be due to the increase of the steric hindrance and the $\sigma$-inductive effect. For complex 1, as mentioned in Section 2.4 , the pyrazole moiety lies essentially on the square-plane of the metal complex, with a Cl1-Pt1-N2-C3 torsion angle of $159.0(3)^{\circ}$. In addition the isopropyl function of the isopropylamine ligand is pointing away from the metal center, with the Cl1-Pt1-N6-C7 torsion angle being close to the dihedral angle between the Pt1-N6-C7, with a value of $-104.21(29)^{\circ}$ shows that the iPram ligand adopts the configuration that places the methyl group as far as possible from the chloride ligands. This allows an easier nucleophilic attack by the first GMP molecules above and below the square-plane than in complexes $\mathbf{2}$ and 3. Complex $\mathbf{2}$, which crystallized in two residues (Fig. S1). The major difference between them is the conformation of the iPram ligand with a Pt1-N12-C17-H17 torsion angle of $53.27^{\circ}$ in residue $\mathrm{A}$, and $\mathrm{Pt} 2-\mathrm{N} 22-\mathrm{C} 27-\mathrm{H} 27$ of $-48.65^{\circ}$ in residue B. Therefore, these values of torsion angles show that the iPram ligand is oriented out of the equatorial plane around the platinum center. In this case, the methyl group is further removed from the metal center, thus not impacting directly on the site of the nucleophilic attack above and below the square-plane. However, the iPram functionality, which is oriented out of the equatorial plane, does result in some steric hindrance to the approaching nucleophile. For complex 3, the presence of the methyl group next to the coordination position to the metal center, leads to increase of the steric hindrance and a marked retardation of rate constant for the forward reaction. The pyrazole ring is located completely perpendicular to the equatorial plane due to the steric hindrance of its methyl group in the $\mathrm{N}$ next to the coordination position. The iPram ligand has different torsion angles $-99.17^{\circ}$ and $-70.82^{\circ}$ according to its different conformations. These values of torsion angles show a perpendicular disposition of the iPram ligand respect the equatorial plane. Essentially this blocks the nucleophilic attack on one side of the square-plane and account for the retardation in the rate constant, $k_{1}$.

Comparing the first and second substitution for complex 3 , it is observed that the second substitution is faster by a factor of 2. This is contrary to what one would expect, noting that GMP is bulky and would have hindered the second molecule from entering the coordination sphere. The possible explanation for an accelerated second substitution is the nature of the leaving group. The first substitution involved $\mathrm{Cl}^{-}$ion as the leaving group and in the second process through the hydrolysis of the second $\mathrm{Cl}^{-}$atom, the $\mathrm{H}_{2} \mathrm{O}$ molecule, which is more labile, becomes the leaving group, accounting for the slight increase.

\subsection{Cytotoxicity properties}

The growth inhibiting effect of compounds $\mathbf{1}, \mathbf{2}$ and $\mathbf{3}$ was tested on nine different human tumor cell lines and compared to cisplatin. The resultant $\mathrm{IC}_{50}$ values obtained in MCF7 and EVSA-T (breast cancer), WIDR (colon cancer), IGROV (ovarian cancer), M19 (melanoma), A498 (renal cancer), H226 (non-small cell lung cancer) and A2780 (ovarian cancer) sensitive and resistant to cisplatin, are summarized in Table 6 and 7. Clearly the asymmetric trans complex 1 shows high cytotoxicity in the EVSA-T and IGROV cell lines and in a lesser extent in the H226 cell line. Complex 2 also shows high cytotoxicity in these three particular cell lines. Complex $\mathbf{3}$ is the least active compound from this series, although it still shows cytotoxicity in the micromolar range, especially in the EVSA-T and IGROV cell lines. Furthermore, in the interest of finding improved alternatives to cisplatin in second or third line treatment, the activity of the compounds in the A2780 and A2780res cell lines was compared (Table 6). In the A2780res cell line decreased uptake of cisplatin is observed

Table 5

Summary of rate constants for the direct and solvolytic substitution pathways for the reaction of complexes 1, 2 and $\mathbf{3}$ with GMP

\begin{tabular}{llll}
\hline Rate constants & $\mathbf{1}$ & $\mathbf{2}$ & $\mathbf{3}$ \\
\hline$k_{1}, \mathrm{M}^{-1} \mathrm{~s}^{-1}$ & $(1.86 \pm 0.05) \times 10^{-2}$ & $(2.16 \pm 0.30) \times 10^{-4}$ & $(7.55 \pm 0.33) \times 10^{-5}$ \\
$k_{-1}, \mathrm{~s}^{-1}$ & $(2.12 \pm 0.05) \times 10^{-4}$ & $(1.51 \pm 0.24) \times 10^{-5}$ & $(4.04 \pm 0.03) \times 10^{-5}$ \\
$k_{2}, \mathrm{M}^{-1} \mathrm{~s}^{-1}$ & & & $(1.61 \pm 0.20) \times 10^{-4}$ \\
$k_{-2}, \mathrm{~s}^{-1}$ & & & $(2.79 \pm 0.23) \times 10^{-5}$ \\
\hline
\end{tabular}


Table 6

In vitro cytotoxicity assay of the asymmetric trans-platinum(II) complexes and cisplatin in human tumor cell lines ${ }^{\mathrm{a}}$

\begin{tabular}{lcllcccc}
\hline Test compound & $\mathrm{IC}_{50}(\mu \mathrm{M})$ \\
\cline { 2 - 8 } & $\mathrm{MCF} 7$ & EVSA-T & WIDR & IGROV & M19 & A498 & H226 \\
\hline $\mathbf{1}$ & 4.21 & 1.56 & 7.74 & 1.88 & 6.41 & 9.79 & 12.76 \\
$\mathbf{2}$ & 5.52 & 2.86 & 10.69 & 3.66 & 7.4 & 19.31 & 18.81 \\
$\mathbf{3}$ & 18 & 8.4 & 25.4 & 10.3 & 19 & 55.2 & 28.7 \\
Cisplatin & 1.42 & 1.42 & 1.78 & 0.43 & 1.84 & 5.75 & 4.53 \\
\hline
\end{tabular}

${ }^{\mathrm{a}}$ MCF7: breast cancer; EVSA-T: breast cancer; WIDR: colon cancer; IGROV: ovarian cancer; M19: melanoma; A498: renal cancer; H226: nonsmall cell lung cancer.

Table 7

In vitro cytotoxicity assay of the trans-platinum(II) complexes and cisplatin on A2780 ovarian cancer cell lines sensitive (A2780) and resistant (A2780res) to cisplatin

\begin{tabular}{llll}
\hline Test compound & \multicolumn{3}{l}{$\mathrm{IC}_{50}(\mu \mathrm{M})$} \\
\cline { 2 - 4 } & $\mathrm{A} 2780$ & A2780res & $\mathrm{RF}^{\mathrm{a}}$ \\
\hline $\mathbf{1}$ & $25 \pm 0.23$ & $11 \pm 1.0$ & 0.44 \\
$\mathbf{2}$ & $21 \pm 0.60$ & $14 \pm 3.5$ & 0.66 \\
$\mathbf{3}$ & $49 \pm 0.30$ & $21 \pm 0.5$ & 0.43 \\
Cisplatin & $3 \pm 0.16$ & $24 \pm 0.45$ & 8 \\
\hline
\end{tabular}

${ }^{\mathrm{a}} \mathrm{RF}$ (resistant factor), relative ratio of $\mathrm{IC}_{50}$ values in both cell lines (A2780res/A2780).

as well as enhanced DNA repair, increased DNA damage tolerance and elevated glutathione (GSH) levels compared to the parent cell line A2780 [44]. As a result cisplatin shows an 8-fold decrease in activity in the A2780res compared to the A2780 cell line as shown in Table 6 as the resistance factor (RF). In contrast, compounds $\mathbf{1}, \mathbf{2}$ and $\mathbf{3}$ show higher activities in the A2780res cell line compared to the A2780 cell line. This is illustrated by the RF values lower than 1 . This implies that all asymmetric trans platinum complexes presented in the current study could present improved alternatives to cisplatin in second or third line treatment.

\section{Discussion and conclusions}

In the present paper, three new asymmetric trans-platinum complexes are synthesized and fully characterized. In addition the stability and reactivity of the complexes were investigated as well as the in vitro cytotoxicity in a large panel of human tumor cell lines. Interestingly, it was observed that out of the three complexes, complex 3 reacted slower with the DNA model base GMP and also showed the lowest cytotoxic activity. Conversely, compound 2 reacted at a higher rate than complex 1 with GMP, but complex 1 was found the most active compound in the in vitro evaluation. The difference between the three complexes lies in their azole ligand. The methyl group adjacent to the $\mathrm{N}$ coordinating to platinum in complex $\mathbf{3}$, increases the steric bulk around the platinum atom. This slows down the coordination of platinum to GMP as well as to DNA, as it can be observed in the rate constant values, thus decreasing the cytotoxic effect of compound 3 . In complex $\mathbf{2}$ the methyl group is pointing away from the platinum atom and therefore does not interfere with the substitution of the chloride atoms for a molecule of GMP. Similarly the coordination of GMP is not hindered by steric factors in complex $\mathbf{1}$, with a rate constant, $k_{1}$, of $1.86 \times 10^{-2} \mathrm{M}^{-1} \mathrm{~s}^{-1}$. In addition to the steric effect, an increase in the cis $\sigma$-effect $[45,46]$ is present with respect to the leaving group through the introduction of the methyl moiety in both $\mathbf{2}$ and $\mathbf{3}$. The net effect is the accumulation of the electronic density at the metal center, making it less electrophilic. This slows down the substitution reaction by repelling the incoming GMP.

To explain the difference in cytotoxic behavior between these two complexes, one must therefore consider that complex 1 can form hydrogen bonds with the NH functionality, as observed in the solid-state crystal structure, whereas complex 2 cannot. In the case where either of the complexes is bound monofunctionally to DNA, complex 1 can have additional interaction with the adjacent nucleobase through hydrogen bonding. Complex $\mathbf{2}$ is unable to do this. It is likely that this difference leads to the increased in vitro activity of complex $\mathbf{1}$ compared to complex 2. As expected for trans-platinum complexes with planar aromatic ligands, all three complexes overcome cisplatin resistance in the A2780res cell line. It is this result in combination with the high cytotoxicity observed in the other cell lines that shows the potential of these complexes as alternatives to cisplatin in second line treatment. Currently studies are ongoing to gain a better insight in the DNA binding behavior of the complexes, which may be used to understand the activity of the complexes and in the design of further improved asymmetric trans-platinum complexes for antitumor evaluation.

\section{Abbreviations}

A2780 a human ovarian carcinoma cell line

A2780R cisplatin resistant human ovarian carcinoma cell line

A498 a renal cancer cell line

d doublet

DMEM Dulbecco's Modified Eagle Medium

DMF dimethylformamide

DMSO dimethyl sulfoxide

EVSA-T a breast cancer cell line

GMP guanosine 5'-monophosphate

H226 non-small cell lung cancer

$\mathrm{Hpz} \quad$ pyrazole

IGROV an ovarian cancer cell line

iPram isopropylamine

M19 a melanoma cell line

MCF7 a breast cancer cell line

Meim 1-methylimidazole

Mepz 1-methylpyrazole 


$\begin{array}{ll}\text { MTT } & \begin{array}{l}\text { 3-(4,5-dimethylthiazol-2-yl)-2,5-diphenyl-2 } \mathrm{H}- \\ \text { tetrazolium bromide }\end{array} \\ \text { RF } & \begin{array}{l}\text { resistant factor } \\ \text { singlet }\end{array} \\ \text { sept } & \text { septuplet } \\ \text { t } & \text { triplet } \\ \text { TMS } & \text { trimethylsilane } \\ \text { WIDR } & \text { a colon cancer cell line }\end{array}$

\section{Acknowledgements}

The authors wish to thank Johnson \& Matthey (Reading, UK) for their generous loan of $\mathrm{K}_{2} \mathrm{PtCl}_{4}$. Also the support and sponsorship concerted by COST Actions D20/ 0001/00, D20/0002/00 and D20/003/01 and Spanish CYCIT (SAF 03/01700) are kindly acknowledged. This work was supported by the council for Chemical Sciences of the Netherlands Organization for Scientific Research (CW-NWO). The tests of the compounds were supported by PCN Nederland (Pharmachemie, Haarlem).

\section{Appendix A. Supplementary data}

Supplementary data associated with this article can be found, in the online version, at doi:10.1016/j.jinorgbio. 2006.09.015.

\section{References}

[1] L.R. Kelland, S.J. Clarke, M.J. McKeage, Plat. Met. Rev. 36 (1992) 178-184.

[2] M.J. Abrams, B.A. Murrer, Science 261 (1993) 725-730.

[3] D.D. Vonhoff, R. Schilsky, C.M. Reichert, R.L. Reddick, M. Rozencweig, R.C. Young, F.M. Muggia, Cancer Treat. Rep. 63 (1979) $1527-1531$.

[4] T.J. McMillan, T.C. Stephens, G.G. Steel, Br. J. Cancer 52 (1985) $823-832$.

[5] T.J. McMillan, T.C. Stephens, G.G. Steel, Br. J. Cancer 52 (1985) 453.

[6] T.A. Connors, M. Jones, W.C.J. Ross, P.D. Braddock, A.R. Khokhar, M.L. Tobe, Chem. Biol. Interact. 5 (1972) 415-424.

[7] P.D. Braddock, T.A. Connors, M. Jones, A.R. Khokhar, D.H. Melzack, M.L. Tobe, Chem. Biol. Interact. 11 (1975) 145-161.

[8] N. Farrell, Transition Metal Complexes as Drugs and Chemotherapeutic Agents, Kluwer, Dordrecht, The Netherlands, 1989.

[9] A. Eastman, Cisplatin, Chemistry and Biochemistry of a leading Anticancer Drug, Wiley-VCH, Basel, Switzerland, 1999.

[10] T.W. Hambley, J. Chem. Soc. Dalton Trans. 19 (2001) 2711-2718.

[11] N. Boogaard, C. Altona, J. Reedijk, J. Inorg. Biochem. 49 (1993) $129-147$.

[12] J. Reedijk, Curr. Opin. Chem. Biol. 3 (1999) 236-240.

[13] L. Fourrier, P. Brooks, J.M. Malinge, J. Biol. Chem. 278 (2003) $21267-21275$

[14] R. Dalbies, D. Payet, M. Leng, Proc. Natl. Acad. Sci. USA 91 (1994) $8147-8151$.

[15] M. Van Beusichem, N. Farrell, Inorg. Chem. 31 (1992) 634-639.

[16] N. Farrell, Current status of structure-activity relationships of platinum anticancer drugs: Activation of the trans-geometry, Marcel Dekker, Inc., Basel, Switzerland, 1996.
[17] N. Farrell, L.R. Kelland, J.D. Roberts, M. Van Beusichem, Cancer Res. 52 (1992) 5065-5072.

[18] J. Jawbry, I. Freikman, Y. Najajreh, J.M. Perez, D. Gibson, J. Inorg. Biochem. 99 (2005) 1983-1991.

[19] Y. Najajreh, J. Kasparkova, V. Marini, D. Gibson, V. Brabec, J. Biol. Inorg. Chem. 10 (2005) 722-731.

[20] V. Brabec, personal communication (2005).

[21] G. Natile, M. Coluccia, Coord. Chem. Rev. 216-217 (2001) 383-410.

[22] Y. Chen, Z.J. Guo, J.A. Parkinson, P.J. Sadler, J. Chem. Soc. Dalton Trans. (1998) 3577-3585.

[23] L.R. Kelland, C.F.J. Barnard, I.G. Evans, B.A. Murrer, B.R.C Theobald, S.B. Wyer, P.M. Goddard, M. Jones, M. Valenti, A. Bryant, P.M. Rogers, K.R. Harrap, J. Med. Chem. 38 (1995) 3016-3024.

[24] G.M. Sheldrick, SADABS Program for Empirical Absorption Correction, Bruker AXS, Karlsruhe, Germany, 2003.

[25] P.T. Beurskens, G. Admiraal, G. Beurskens, W.P. Bosman, S. Garcica-Granda, R.O. Gould, J.M.M. Smits, C. Smykalla, The DIRDIF program system Technical report of the Crystallography Laboratory, University of Nijmegen, Nijmegen, The Netherlands, 1992.

[26] G.M. Sheldrick, SHELDXS86 Program for Crystal Structure Solution, University of Göttingen, Göttingen, Germany, 1997.

[27] G.M. Sheldrick, SHELXL97 Program for Crystal Structure refinemented, University of Göttingen, Göttingen, Germany, 1997.

[28] A.L. Spek, J. Appl. Crystallogr. 36 (2003) 7-13.

[29] M.R. Boyd, Princ. Pract. Oncol. 3 (1989) 1-12.

[30] Y.P. Keepers, P.E. Pizao, G.J. Peters, J. Vanarkotte, B. Winograd, H.M. Pinedo, Eur. J. Cancer 27 (1991) 897-900.

[31] A. Eva, K.C. Robbins, P.R. Andersen, A. Srinivasan, S.R. Tronick, E.P. Reddy, N.W. Ellmore, A.T. Galen, J.A. Lautenberger, T.S. Papas, E.H. Westin, F. Wongstaal, R.C. Gallo, S.A. Aaronson, Nature 295 (1982) 116-119.

[32] M.C. Alley, D.A. Scudiero, A. Monks, M.L. Hursey, M.J. Czerwinski, D.L. Fine, B.J. Abbott, J.G. Mayo, R.H. Shoemaker, M.R. Boyd, Cancer Res. 48 (1988) 589-601.

[33] Microcal $^{\mathrm{TM}}$ Origin $^{\mathrm{TM}}$ Version 5.0, Microcal Software, Inc., One Roundhouse Plaza, Northampton, MA, 01060, USA, 19911997.

[34] T.G. Appleton, J.R. Hall, S.F. Ralph, C.S.M. Thompson, Inorg. Chem. 23 (1984) 3521-3525.

[35] T.G. Appleton, J.R. Hall, S.F. Ralph, Inorg. Chem. 24 (1985) 673677.

[36] T.G. Appleton, J.R. Hall, S.F. Ralph, Inorg. Chem. 24 (1985) 4685 4693.

[37] K. Nakamoto, P.J. McCarthy, J. Fujita, R.A. Condrate, G.T. Behnke, Inorg. Chem. 4 (1965) 36-43.

[38] U. Bierbach, N. Farrell, Inorg. Chem. 36 (1997) 3657-3665.

[39] J.M. Perez, E.I. Montero, A.M. González, X. Solans, M. FontBardia, M.A. Fuertes, C. Alonso, C. Navarro-Ranninger, J. Med. Chem. 43 (2000) 2411-2418.

[40] S. Komeda, G.V. Kalayda, M. Lutz, A.L. Spek, Y. Yamanaka, T. Sato, M. Chikuma, J. Reedijk, J. Med. Chem. 46 (2003) 12101219.

[41] I.M. Ismail, P.J. Sadler, ACS Sym. Ser. 209 (1983) 171-190.

[42] D.P. Bancroft, C.A. Lepre, S.J. Lippard, J. Am. Chem. Soc. 112 (1990) 6860-6871.

[43] U. Bierbach, Y. Qu, T.W. Hambley, J. Peroutka, H.L. Nguyen, M. Doedee, N. Farrell, Inorg. Chem. 38 (1999) 3535-3542.

[44] Y. Najajreh, J.M. Pérez, C. Navarro-Ranninger, D. Gibson, J. Med. Chem. 45 (2002) 5189-5195.

[45] A. Hofmann, L. Dahlenburg, R. Van Eldik, Inorg. Chem. 42 (2003) 6528-6535.

[46] D. Jaganyi, D. Reddy, J.A. Gertenbach, A. Hofmann, R. van Eldik, Dalton Trans. (2004) 299-306. 